\title{
ELEKTRONINIŲ CIGAREČIŲ PAPLITIMAS IR RIZIKA VAIKŲ BEI JAUNIMO SVEIKATAI
}

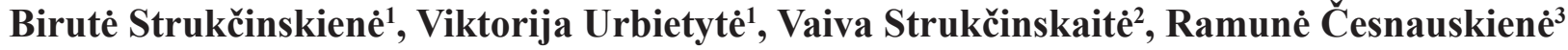 \\ ${ }^{1}$ Klaipédos universiteto Sveikatos mokslu fakultetas, ${ }^{2}$ Vilniaus universiteto Medicinos fakultetas, \\ ${ }^{3}$ Kauno kolegijos Medicinos fakultetas
}

Raktažodžiai: elektroninès cigaretès, sveikata, vaikai, jaunimas.

\begin{abstract}
Santrauka
Elektroninès cigaretès į rinką išleistos vos prieš dešimtmetí, tad vis dar pasigendama svarių mokslinių irodymų apie jų riziką sveikatai. Darbo tikslas - analizuoti elektroninių cigarečių paplitimą ir riziką vaiku bei jaunimo sveikatai. Taikyta sisteminè mokslinès literatūros bei dokumentų apžvalga ir analizè.

Rezultatai ir išvados. Atlikti tyrimai rodo, kad visuomené yra nepakankamai informuota apie elektroninių cigarečių žalą vaikų ir jaunimo sveikatai. Stinga tinkamo dèmesio elektroninių cigarečių vartojimo prevencijai ir kontrolei. Ivairiose pasaulio šalyse skirtingas elektroninių cigarečių vartojimo reglamentavimas bei valdymas, tad rekomenduojama atsižvelgti i užsienio šalių gerosios patirties pavyzdžius ir taikytą praktiką.
\end{abstract}

\section{Ivadas}

Elektronines cigaretes 2003 m. išrado Kinijos vaistininkas Honas Likas, kaip alternatyvą tradicinėms cigaretėms [1]. Praejjus ketveriems metams, elektroninès cigaretès buvo patentuotos pasauliniu mastu ir vèliau išleistos ị pasaulinę rinką [2]. 2010 m. padidèjo elektroninių cigarečių vartojimas tarp suaugusiujų ir jaunimo [3]. $2017 \mathrm{~m}$. Europoje apie 25 proc. 15-25 metų jaunuolių jau buvo bandę elektroninių cigarečių skoni [4]. Atlikti tyrimai rodo, kad dauguma elektroninių cigarečių vartotojų anksčiau rūkẻ tabako gaminius. Didžioji dalis žmonių mano, kad elektroninès cigaretès padès sumažinti surūkomu ịprastinių cigarečiu kiekị [3]. Elektroninès cigaretès tampa vis patrauklesnès tarp vaikų ir jaunimo, nes, priešingai nei klasikinès, jos neturi kvapo ir gali būti ịvairaus skonio [5]. Amerikos maisto ir vaistų administracijos (angl. Food and Drugs Administration, sutr. FDA) atliktame tyrime buvo lyginami kancerogeninių medžiagų vidutiniai kiekiai elektroninès cigaretės aerozolyje su kiekiu, esančiu tradicinèse tabako cigaretėse. Nustatyta, kad toksinių medžiagų kiekiai elektroninès cigaretės aerozolyje buvo mažesni, nei tradicinių cigarečių dūmuose, tačiau elektroninių cigarečių aerozolyje susidaro sunkieji metalai, kurių nerandama tradicinėse cigaretėse. Moksliniais tyrimais pagrịsta, kad elektroninių cigarečių aerozolyje yra kancerogeninių medžiagų, kurios veikia vartotoją, tačiau ilgalaikis jų poveikis nenustatytas [1]. Ypač aktualu tyrinèti elektroninių cigarečių riziką ir poveikị vaikų ir jaunų žmonių sveikatai, nagrinèti, ar pakanka reglamentų ir elektroninių cigarečių kontrolès bei prevencijos priemonių, skirtų mažinti šią naują grèsmę visuomenès sveikatai.

Darbo tikslas - analizuoti elektroninių cigarečių paplitimą ir riziką vaikų bei jaunimo sveikatai.

\section{Tyrimo objektas ir metodika}

Buvo taikyta sisteminè mokslinès literatūros bei dokumentų apžvalga ir analizè. Tyrimui paieška vykdyta PubMed duomenų bazeje, informacijos pateikimo sistemoje Google Scholar ir Lietuvos Respublikos Seimo portalo Dokumentų paieškos skiltyje. Atrinkti anglų ir lietuvių kalbomis publikuoti straipsniai bei reglamentai elektroninių cigarečių apibū-dinimo, paplitimo, rizikos sveikatai, valdymo ir kontrolès klausimais.

\section{Rezultatai}

Elektroninių cigarečių veikimo principas. Rūkymo metu skystis, esantis elektroninejje cigareteje, kaitinamas auštesneje nei $200{ }^{\circ} \mathrm{C}$ temperatūroje (priklausomai nuo cigaretès modelio). Susidaro aerozolis, kuris įkvepiamas. Šiuo būdu garų pavidalu ị organizmą patenka elektroninès cigaretės skystyje esančios medžiagos [6]. Mokslinėse studijose tyrejjai daro prielaidą, kad elektroninių cigarečių rūkymas yra mažiau kenksmingas sveikatai, negu tradicinių, tačiau atliktų tyrimų rezultatai yra labai skirtingi ir prieštaringi.

Elektroninè cigarete yra prietaisas, susidedantis iš 3 dalių: 
skysčiu užpildytos kasetès, kaitiklio bei baterijos. Nuspaudus mygtuką, ijungiamas kaitiklis, kuris šildo skystį, o šiam tapus garais, jie ịtraukiami ị plaučius [3]. Elektroninès cigaretès būna vienkartinès (keičiamos vienkartinès kapsulès) arba daugkartinès (naudojamos pildyklès) [7]. Elektroninès cigaretès susideda iš įvairios formos prietaisų, kurie ịkaitina elektroninių cigarečiu skysti, dažniausiai susidedantị iš nikotino, propilenglikolio, glicerolio, skonį ir kvapą suteikiančių medžiagų ir kitų priedų (1 pav.), o garų aerozoli ịkvepia vartotojas [5].

Elektroninès cigaretès yra ịvairių modelių ir formų. Anglų kalboje jos vadinamos ịvairiai, pvz.: e-cigarettes, e-cigs, cigalikes, e-hookahs, mods, vape pens, vapes, tank systems, tačiau visų veikimo principas vienodas - vartotojas ịkvepia garus, kurie susidaro kaitinant elektroninių cigarečių skystị [5]. Dažniausiai elektroninès cigaretès gaminamos taip, kad imituotų tradicines, atitiktų jų dydį ir formą ( 2 pav.). Pagrindinis elektroninių ir tradicinių cigarečių skirtumas yra tas, kad elektroninių cigarečių rūkymo metu nedeginamas tabakas [8]. Lietuvos ir pasaulio prekybos vietose galima rasti penkių pagrindinių kategorijų skysčių skonio elektroninių cigarečių: tabako, vaisių, mentolio, saldumynų bei kitokių (pvz., kavos, energinių gèrimų) [4, 5, 7].

Elektroninių cigarečių vartojimo paplitimas. Elektroninès cigaretès per pastaruosius kelerius metus tapo populiari alternatyva tradicinèms ne tik Lietuvoje, bet ir pasaulyje. 2017 m. „Eurobarometro“ tyrimo Europoje duomenimis, beveik 1 iš dešimties ( 9 proc.) respondentų bande elektroninę cigaretę nors 1-2 kartus, bet reguliariai rūkè tik apie 2 proc. apklaustujų. Apžvelgiant rezultatus šalių lygmenimis, konstatuota, kad Jungtinèje Karalysteje elektronines cigaretes rūkẻ 5 proc. visų respondentų. Aukštas rezultatas pastebėtas ir Prancūzijoje, lyginant tuos, kurie rūke elektronines cigaretes ir daugiau neberūko - 9 procentai. Tarp rūkančiųu kiekvieną dieną, elektronines cigaretes rūkẻ vyrai (71 proc.), dažniau nei moterys (57 proc.) ir mažiau išsilavinę asmenys (81 proc.) bei bedarbiai (45 proc.). 52 proc. respondentų,

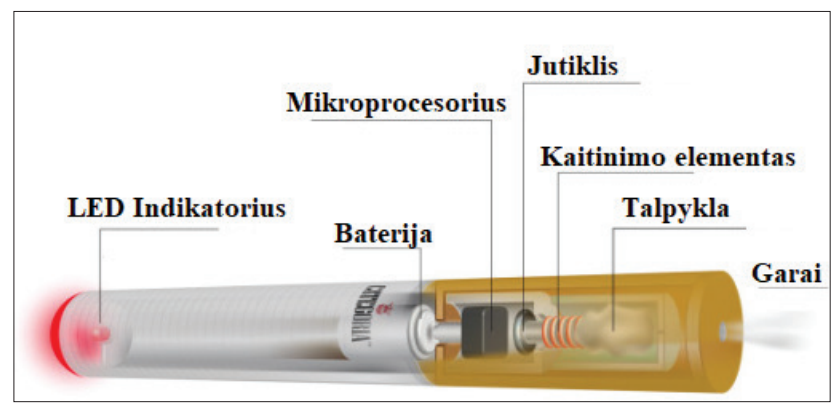

1 pav. Elektroninès cigaretès struktūra (pagal T. Petrulionienę, 2018). lyginant pagal amžiaus grupes, buvo 15-24 metų [4].

Elektroninių cigarečiu vartojimas per pastaruosius metus ypač išaugo Jungtinėse Amerikos Valstijose (JAV). Amerikiečių mokslininkų $2016 \mathrm{~m}$. atliktas suaugusiųjų tyrimas parode, kad elektronines cigaretes vartojo 4,5 proc. respondentu. Didžiausias vartojimas buvo stebimas tarp 18-24 metu jaunuolių ( 9,2 proc.). Daugiau nei pusè rūkalių (51,2 proc.) buvo jaunesni nei 35 metų. Pastebèti skirtumai tarp lyčių: vyrai dažniau rūkè elektronines cigaretes, nei moterys [9].

Nuo 2014 m. JAV elektroninès cigaretės yra populiariausias nikotino produktas tarp jaunų žmonių. Apžvelgus JAV Nacionalinės jaunimo tabako apklausos (angl. National Youth Tobacco Survey, sutr. NYTS) $2015 \mathrm{~m}$. ataskaitos rezultatus, pastebeta, kad 13,5 proc. vidurinès mokyklos mokiniu (11-14 m.) bei 37,7 proc. 14-18 metų jaunuolių yra bandę elektronines cigaretes. Matomi reikšmingi skirtumai tarp berniukų ir mergaičių, etninès kilmès bei rasès. Be to, kasmet vykdomas tyrimas leido daryti prielaidą, kad elektroninių cigarečių vartojimas tarp mokyklinio amžiaus vaikų kasmet didejo: $2011 \mathrm{~m} .3,3$ proc., 2012 - 6,8 proc., 2013 - 8,1 proc., 2014 - 19,8 proc., 2015 metais- 27 proc. [10].

JAV atliktame tyrime paaiškejjo, kad tik pusè (51 proc.) 16-18 m. asmenų, girdejjusių apie elektronines cigaretes, žino, kad jų sudètyje yra nikotino, o Lietuvoje trečdalis $(32,3$ proc.) jaunimo yra blogai ar labai blogai informuoti apie elektroninių cigarečių rūkymo pasekmes [11].

2014 m. Europos šalyse elektronines cigaretes rūkẻ 12 proc. žmonių, dažniau - jaunimas. Jie dažniausiai rinkosi elektronines cigaretes su nikotinu. Suaugusių Lietuvos žmonių gyvensenos tyrimo duomenimis, $2014 \mathrm{~m}$. kasdien rūkẻ 33 proc. vyrų ir 12 proc. moterų. 11,4 proc. kasdien ir retkarčiais

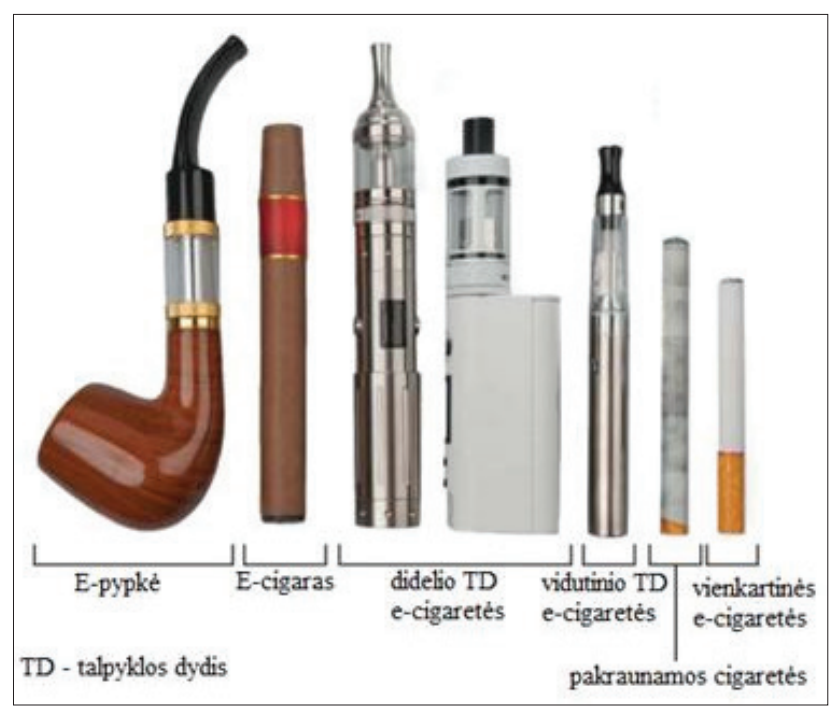

2 pav. Elektroninių cigarečių rūšys (pagal T. Petrulionienę, 2018). 
rūkančių vyrų ir 10,1 proc. moterų atsakè, kad per praejjusius metus jie rūké elektronines cigaretes [12].

Lietuvoje Narkotiku, tabako ir alkoholio kontrolès departamento atlikto tyrimo metu buvo nustatyta, kad elektronines cigaretes nors kartą gyvenime rūkè 9,2 proc. jaunimo, o per pastaruosius 12 mènesių $-3,8$ procento. Per pastarąsias 30 dienų elektronines cigaretes nurodè rūkę tik 4 tyrimo dalyviai ( 1,7 proc.), bet nè vienas iš jų šio gaminio nevartojo kasdien. Elektronines cigaretes paprastai išbando jaunimas, kuris jau rūko tabako gaminius ar juos rūkè praeityje. Tyrimo dalyviai, kurie nebandè rūkyti tabako gaminių (cigarečių, cigarų, pypkių), nebandè ir elektroninių cigarečių (0 proc.), o tarp rūkiusių tabako gaminius nors kartą gyvenime elektronines cigaretes išbande 12,2 procento [11].

Elektroninių cigarečių rizika vaikų ir jaunimo sveikatai. Elektroninès cigaretės rinkoje atsirado prieš dešimtmetí, todèl ilgalaikis jų vartojimo poveikis sveikatai nèra galutinai ištirtas. Manoma, kad elektroninès cigaretės turètų būti saugesnès, nei ịprastinès [1]. Esant dabartiniam rūkymo paplitimui, manoma, kad 5,6 mln. JAV gyventojų, jaunesnių nei 18 metų, per anksti mirs nuo rūkymo sukeltų ligų [13]. Amerikos maisto ir vaistų administracija išanalizavo du populiariausius elektroninių cigarečių prekinius ženklus, kuriuose rado ịvairių lygių kancerogenų ir nikotino.

Nikotino poveikis. Tradicinių ir elektroninių cigarečių sudetyje esantis nikotinas didina jų vartotojų širdies susitraukimų dažnį, o kraujyje susidaro reikšmingai didelis nikotino metabolito - kotinino kiekis. İtraukiamo ir ị kraują patenkančio nikotino kiekis skiriasi. Jis priklauso nuo nikotino koncentracijos skystyje, kitų skysčio komponentų, vartotojo patirties, itraukimų intensyvumo, prietaiso charakteristikos bei garinimo technikos. Patyrę elektroninių cigarečių vartotojai dažniausiai ịtraukia garus giliau, o prietaisą naudoja kur kas intensyviau, nei pradedantieji, todèl jų kraujyje nikotino kiekis yra didesnis ir beveik prilygsta susidarančiam rūkant iprastines cigaretes [3]. Elektroninių cigarečių poveikis vaikų sveikatai nèra pakankamai ištirtas, tačiau mokslininkai susirūpinę dèl nikotino poveikio jaunimo bei vaikų sveikatai. Ankstesni tyrimai rodo, kad augančiam organizmui nikotinas ir koncerogeninès medžiagos daro negrịžtamą žalą. Atlikus tyrimą su vaikais ir paaugliais nustatyta, kad nikotino poveikis turi žalingą poveikị smegenims, ịskaitant pažintinius gebėjimus, bei raidą. Nedidelè dozė nikotino vaikui yra toksiška, tad gali sukelti pykinimą, vėmimą, viduriavimą, seilètekị ar traukulius [14].

Garų poveikis. Elektroninių cigarečių garai skiriasi nuo ịprastinių cigarečių dūmų. Juose nèra dervų. Kai kurie ekspertai mano, kad įkvejpti elektroninių cigarečių garus yra mažiau kenksminga, nei cigarečių dūmus [3]. Moksliniuose tyrimuose nustatyta, kad elektroninių cigarečių aerozolyje yra ne tik nikotino, bet ir kitų potencialiai toksiškų junginių (karbonilų, metalų, kietujų dalelių) bei didelis propilenglikolio ir glicerolio kiekis [15]. Vis dar mažai žinoma apie išgarinto propilenglikolio ir glicerolio saugumą, galimą kancerogenini poveikị. Mokslininkai teigia, kad propilenglikolis, aptinkamas elektroninių cigarečių skystyje, gali sukelti viršutinių ir apatinių kvèpavimo takų infekciją, pneumoniją ir suaktyvinti bronchitą [1]. Skildamas aukštoje temperatūroje, propilenglikolis gali sudaryti propilenoksidą, kuris gali būti koncerogeniškas žmonemms. Kaistant gliceroliui, gali susidaryti toksinas akroleinas, dirginantis kvejpavimo takus, sukeliantis sausą kosulį, dusuli, galvos svaigimą, pykinimą $[3,16]$. Elektroninių cigarečių poveikis plaučių ląstelèms yra toks pats žalingas, kaip ir tradicinių cigarečiu rūkymas. Ir tradicinès, ir elektroninès cigaretės daro ịtaką mitochondrijų funkcijai, kurios sutrikimai sukelia kvèpavimo takų uždegimą, destrukciją ir plaučių vėži [17]. Nors kai kurių kancerogeninių medžiagų kiekis elektroninèse cigaretėse gali būti mažesnis, nei tradicinėse, rizika ir žala žmogaus sveikatai išlieka [18]. Daugelio toksinių medžiagų kiekiai aerozoliuose yra iki 22 kartų ar daugiau didesni, nei tradicinèse cigaretėse [18]. Elektroninių cigarečių vartojimo rizika žmonių, o ypač vaikų ir jaunimo sveikatai, kelia nerimą pasaulio mokslininkų bendruomenei. Žala ir rizika kvẻpavimo sistemai, organizmo sensibilizacija ir kancerogeninis poveikis turi būti toliau tiriamas ir pagrịstas ịrodymais. Sveikatos specialistų pastangas reguliuoti elektroninių cigarečių vartojimą, mažinti aplinkos taršą elektroninių cigarečių garais, užtikrinti sveiką ir saugią vaikų, paauglių ir jaunimo aplinką, privalo palaikyti sveikatos politikos formuotojai ir kiti, ne tik su sveikata susiję, sektoriai.

Elektroninių cigarečių vartojimo prevencija ir kontrolė. Visuomenèje kyla susirūpinimas, kad elektroninių cigarečių rūkymas gali paskatinti priklausomybę nikotinui ir padidinti norą išbandyti ịprastines cigaretes. Nerimą kelia ir nepakankamai apribotas elektroninių cigarečių vartojimas viešosiose vietose. Nèra žinoma, kokią įtaką aplinkinių sveikatai gali turèti pasyvusis garinimas. Elektroninių cigarečių reglamentavimas pasaulyje skiriasi ir, laikui begant, kinta [3]. Šiuo metu nèra pakankamai duomenų apie ilgalaikio elektroninių cigarečių rūkymo poveikị sveikatai, todèl reikalingi ịstatymai, reguliuojantys jų pardavimą bei reklamą [16]. 2014 m. priimtos Europos Parlamento ir Tarybos direktyvos 2014/40/ES vienas iš tikslų yra suderinti valstybių narių įstatymus ir kitus teisès aktus, reglamentuojančius elektroninių cigarečių su nikotinu patekimą ị rinką, ženklinimą, reklamą ir kitas sritis [19]. Šios direktyvos nuostatos perkeltos ị Lietuvos Respublikos tabako, tabako gaminių ir su jais susijusių gaminių kontrolès įstatymą, kuriame numatyti elektroninių cigarečių ženklinimo reikalavimai, draudimas rūkyti 
viešojo maitinimo ịstaigose bei kitose viešose vietose [20]. Elektroninių cigarečiu skystis Europos Sajungoje gali būti parduodamas tik tam tikrose pildyklèse, kurių tūris yra ne didesnis nei $10 \mathrm{ml}$, o nikotino koncentracija skystyje negali viršyti $20 \mathrm{mg} / \mathrm{ml}$. Elektroninių cigarečių skysčio pakuotėje turi būti ingredientų sąrašas, šalutinio poveikio, rizikos grupès bei nikotino sukeliamos priklausomybès ir toksiškumo aprašymas [19]. Lietuvoje nuo $2016 \mathrm{~m}$. asmenims, jaunesniems nei 18 metų, draudžiama rūkyti ir turèti elektroninių cigarečių [20; 16 str. 1 d.]. Elektroninèms cigaretèms ir elektroninių cigarečių pildyklėms privalu turèti sustiprintą apsaugą nuo vaikų (įskaitant ịspejjimus apie elektroninių cigarečiu keliamą grèsmę vaikams ar būtinybę jas saugoti nuo vaikų, sudètingesnį ijungimo mechanizmą ar kitas priemones, ribojančias vaikų galimybes naudoti elektronines cigaretes ir kt.), jos turi būti apsaugotos nuo sugadinimo, įskilimo bei pralaidumo ir turèti mechanizmą, kuris užtikrintų, kad jas pildant neištekètų skystis [20; 9 str. 2 d. 5 p.]. Draudžiama parduoti elektronines cigaretes ir jų skysčius, kuriuose yra „vitaminų arba kitų priedų, kurie sudaro ịspūdị, kad elektroninès cigaretės ir elektroninių cigarečiu pildyklès yra naudingos ar mažiau kenksmingos sveikatai; kofeino arba taurino, arba kitų priedų ir stimuliuojamųų junginių, kurie siejami su energija ir gyvybingumu“ [ $[20 ; 9$ str. 2 d. 4 p.].

Nepakankamai ištirtas elektroninių cigarečių skysčiuose esančių medžiagų toksiškumas. Trūksta duomenų apie elektroninių cigarečių, kaip pagalbinès priemonès norintiems mesti rūkius, veiksmingumą ir saugumą. Gydytojas norinčiam mesti rūkius pacientui pirmiausia turètų pasiūlyti patvirtintas pakaitinès nikotino terapijos ar kitas pagalbines priemones ir užtikrinti, kad pacientas gautų informaciją apie naujausius medikamentus, galinčius jam padèti. Jei pacientas atsisako rekomenduojamų priemonių ir renkasi elektronines cigaretes, gydytojas turètų informuoti apie abejotiną ju saugumą ir veiksmingumą [3].

Vaikai ir jaunimas yra menkai informuoti apie elektroninių cigarečių sukeliamą žalą sveikatai, todèl švietimą būtina pradèti ikimokyklinèse įstaigose ir tęsti visą mokymosi ugdymo ịstaigose laikotarpi, teikiant žinias pagal amžių. Prevencinès programos turi būti ilgalaikès, vykdomos formaliai ir neformaliai. Būtina ị prevencijos programas ịtraukti mokinių tėvus, jiems suteikti žinių apie elektroninių cigarečių žalą ir riziką sveikatai, ieškoti bendrų veiklos būdų vaikams, paaugliams ir jauniems žmonėms apsaugoti.

\section{Išvados}

Išnagrinejjus literatūrą ir užsienio mokslininkų atliktus tyrimus, galima teigti, kad nèra pakankamai svarių duomenų, įrodančių, kad elektroninès cigaretès yra sveikesnès už tra- dicines. Trūksta ịrodymų apie elektroninių cigarečių veiksmingumą ir efektyvumą, norintiems mesti rūkius. Nikotinas ir kitos toksinès medžiagos, esančios elektroninių cigarečiu skystyje, dẻl savo kancerogeninio, kvėpavimo sistemą žalojančio poveikio, gali padaryti negrižtamą žalą vaikų ir jaunimo sveikatai. Lietuvoje bei užsienyje atlikti tyrimai rodo, kad visuomenė yra nepakankamai informuota apie elektroninių cigarečių toksiškumą, riziką ir žalą vaikų bei jaunimo sveikatai. Pastaruoju metu elektroninès cigaretès yra viena iš aktualiausių visuomenès sveikatos problemų, nes vis dar stinga tinkamo dėmesio elektroninių cigarečiu vartojimo prevencijai ir kontrolei. İvairiose pasaulio šalyse skirtingas elektroninių cigarečių vartojimo reglamentavimas bei valdymas, tad rekomenduojama atsižvelgti ị užsienio šalių gerosios patirties pavyzdžius ir taikytą praktiką.

\section{Literatūra}

1. Nayir E, Karacabey B, Kirca O, Ozdogan M. Electronic cigarette (e-cigarette). Journal of Oncological Science 2016; 2(1):16-20. https://doi.org/10.1016/j.jons.2016.04.001

2. Kaisar AH, Prasad S, Liles T, Cucullo L. A decade of e-cigarettes: limited research \& unresolved safety concerns. Toxicology 2016; 365:67-75. https://doi.org/10.1016/j.tox.2016.07.020

3. Aleknaitè A., Andrijauskaitè M., Latauskienė J., Andrejevaitė V. Elektroninès cigaretès: naujas būdas mesti rūkyti ar nauja grèsmè? Acta Medica Lituanica 2016;23(1):43-53. https://doi.org/10.6001/actamedica.v23i1.3269

4. Attitudes of Europeans towards tobacco and electronic cigarettes, European Commission. Special Eurobarometer 458. Report 2017. Available at: https://publications.europa.eu/en/ publication-detail/-/publication/2f01a3d1-0af2-11e8-966a01aa75ed71a1/language-en [žiūrèta 18/05/2019].

5. Petrulionienè T. Elektroninès cigaretès. Išsigelbejjimas rūkaliams ir juos supančiai aplinkai? Vilnius: Nacionalinè visuomenès sveikatos priežiūros laboratorija, 2018. http://www.nvspl.lt/popup2.php?m_news_id $=345 \&$ tmpl_name $=\mathrm{m}$ _news_print_form.

6. Canistro D, Vivarelli F, Cirillo S, Marquillas C, Buschini A, Lazzaretti M, et al. E-cigarettes induce toxicological effects that can raise the cancer risk. Scientific Reports 2017; 7(1):2028. https://doi.org/10.1038/s41598-017-02317-8

7. Vileišytė B., Nedzinskienė L. Elektroninès cigaretės: vartojimas, kontrolè ir pasekmè. Literatūros apžvalga. Visuomenès sveikata, 2019; 2(85):22-27.

8. Callahan-Lyon P. Electronic cigarettes: human health effects. Tobacco Control 2014; 23(2): ii36-ii40. https://doi.org/10.1136/tobaccocontrol-2013-051470

9. Mirbolouk M, Charkhchi P, Kianoush S. et al. Prevalence and distribution of e-cigarette use among U.S. adults: behavioral risk factor surveillance system 2016. Annals of Internal Medicine 2018;169(7):429-438. 
https://doi.org/10.7326/M17-3440

10. E-cigarette use among youth and young adults: A Report of the Surgeon General. Atlanta, GA: U.S. Department of Health and Human Services, Centers for Disease Control and Prevention, National Center for Chronic Disease Prevention and Health Promotion, Office on Smoking and Health 2016.

11. Baltrušaitytė R. Alkoholio vartojimo ir rūkymo prevencijos priemonių poreikio ir taikymo jaunimo tikslinèse grupèse galimybių tyrimas. Vilnius: NTAKD, 2013.

12. Klumbienė J., Veryga A., Šakytė E., Petkevičienė J., Grabauskas V. J., Kriaučionienė V. Suaugusių Lietuvos žmonių gyvensenos tyrimas, 2014. Kaunas: LSMU, 2015.

13. Peterson LA, Hecht S S. Tobacco, e-cigarettes, and child health. Current Opinion in Pediatrics 2017; 29(2):225-230. https://doi.org/10.1097/MOP.0000000000000456

14. England LJ, Bunnell RE, Pechacek TF, Tong VT, McAfee TA. Nicotine and the developing human: a neglected element in the electronic cigarette debate. American Journal of Preventive Medicine 2015;49(2):286-293. https://doi.org/10.1016/j.amepre.2015.01.015

15. DeVito EE, Krishnan-Sarin S. E-cigarettes: impact of e-liquid components and device characteristics on nicotine exposure. Current Neuropharmacology 2018; 16(4):438-459. https://doi.org/10.2174/1570159X15666171016164430

16. Kumpauskaitė V. Elektroninès cigaretès. Pulmonologijos naujienos, 2018; 7:18-20.

17. McKelvey K, Popova L, Kim M, Chaffee B, Vijayaraghavan M, Ling P, Halpern-Felsher B. Heated tobacco products likely appeal to adolescents and young adults. Tobacco Control 2018;27:41-47.

https://doi.org/10.1136/tobaccocontrol-2018-054596

18. Glantz S.A. PMI's own in vivo clinical data on biomarkers of potential harm in Americans show that IQOS is not detectably different from conventional cigarettes. Tobacco Control 2018;27(11):9-12.

https://doi.org/10.1136/tobaccocontrol-2018-054413

19. Directive 2014/40/EU of the European Parliament and of the Council of 3 April 2014 on the approximation of the laws, regulations and administrative provisions of the Member States concerning the manufacture, presentation and sale of tobacco and related products and repealing Directive 2001/37/ EC (Text with EEA relevance). http://data.europa.eu/eli/ dir/2014/40/2015-01-06.

20. Lietuvos Respublikos tabako, tabako gaminių ir su jais susijusių gaminių kontrolès įstatymas.

https://e-seimas.1rs.lt/portal/legalAct/lt/TAD/TAIS.24500/ dorCoBXxPG?jfwid=kbavp5efg

\section{MAGNITUDE OF USAGE OF ELECTRONIC CIGARETTES AND RISK FOR HEALTH IN CHILDREN AND YOUNG PEOPLE \\ B. Strukčinskienė, V. Urbietytė, V. Strukčinskaitė, R. Česnauskienè}

Keywords: electronic cigarrettes, health, children, young people.

Summary

Electronic cigarettes were introduced on the market just over a decade ago and there is still lack of considerable scientific evidence on the health risks of electronic cigarettes. The aim of the study was to analyze the prevalence and risk to health of electronic cigarettes in children and young people. A systematic review and analysis of scientific literature and documents was applied.

Results and conclusions. The studies conducted showed that there is a need for awareness rising for society about the health risks of electronic cigarettes for children and young people. Thus, proper attention should be paid to the prevention and control of the usage of electronic cigarettes. The regulation and management of the use of electronic cigarettes differs from country to country and it is recommended to take example from the best practices in foreign countries.

Correspondence to: birutedoctor@hotmail.com

Gauta 2019-10-10 